\title{
ARTICLE Antimicrobial Activity of a Bacteriocin Produced by Enterococcus faecalis KT11 against Some Pathogens and Antibiotic-Resistant Bacteria
}

\author{
Hilal Seval Abanoz ${ }^{1}$ and Buket Kunduhoglu ${ }^{2, *}$ \\ ${ }^{1}$ Institute of Science, University of Eskişehir Osmangazi, 26480 Eskişehir, Turkey \\ ${ }^{2}$ Department of Biology, Faculty of Science and Arts, University of Eskişehir \\ Osmangazi, 26480 Eskişehir, Turkey
}

OPEN ACCESS

\section{Received May 16, 2018 \\ Revised September 24, 2018 \\ Accepted September 26, 2018}

\footnotetext{
*Corresponding author : Buket Kunduhoglu Department of Biology, Faculty of Science and Arts, University of Eskişehir Osmangazi, 26480 Eskişehir, Turkey

Tel: +90 2222393750

Fax: +902222393578

E-mail: bkunduh@gmail.com
}

\begin{abstract}
In this study, the antimicrobial activity of a bacteriocin produced by Enterococcus faecalis KT11, isolated from traditional Karg1 Tulum cheese, was determined, and bacteriocin KT11 was partially characterized. The results showed that bacteriocin KT11 was antagonistically effective against various Gram-positive and Gramnegative test bacteria, including vancomycin- and/or methicillin-resistant bacteria. The activity of bacteriocin KT11 was completely abolished after treatment with proteolytic enzymes (proteinase $\mathrm{K}, \alpha$-chymotrypsin, protease and trypsin), which demonstrates the proteinaceous nature of this bacteriocin. Additionally, bacteriocin KT11 remained stable at $\mathrm{pH}$ values ranging from 2 to 11 and after autoclaving at $121^{\circ} \mathrm{C}$ for $30 \mathrm{~min}$. In addition, the activity of bacteriocin KT11 was stable after treatment with several surfactants (EDTA, SDS, Triton X-100, Tween 80 and urea) and organic solvents (chloroform, propanol, methanol, ethyl alcohol, acetone, hexane and ethyl ether). Cell-free supernatant of $E$. faecalis KT11 was subjected to ammonium sulfate precipitation and then desalted by using a $3.5-\mathrm{kDa}$ cut-off dialysis membrane. The bacteriocin activity was determined to be $711 \mathrm{AU} / \mathrm{mL}$ in the dialysate. After tricine-SDS-PAGE analysis, one peptide band, which had a molecular weight of $\sim 3.5 \mathrm{kDa}$, exhibited antimicrobial activity. Because the bacteriocin KT11, isolated from E. faecalis KT11, exhibits a broad antimicrobial spectrum, heat stability and stability over a wide $\mathrm{pH}$ range, this bacteriocin can be used as a potential bio-preservative in foods. Additionally, bacteriocin KT11 alone or in combination with conventional antibiotics may provide a therapeutic option for the treatment of multidrug-resistant clinical pathogens after further in vivo studies.
\end{abstract}

Keywords antimicrobial peptides, bacteriocin, Enterococcus faecalis, Kargı Tulum cheese

\section{Introduction}

From multicellular microorganisms to bacteria, many organisms produce antimicrobial peptides. Antimicrobial-peptide-producing bacteria are thought to gain a competitive advantage in specific ecological niches. The antimicrobial peptides produced by bacteria are called bacteriocins. In general, bacteriocins have quite a narrow antimicrobial

(C) Korean Society for Food Science of Animal Resources. This is an open access article distributed under the terms of the Creative Commons Attribution Non-Commercial License (http://creativecommons.org/licences/by-nc/3.0) which permits unrestricted non-commercial use, distribution, and reproduction in any medium, provided the original work is properly cited. 
spectrum. Bacteriocins generally exhibit antimicrobial efficacy toward a single species, particularly against species that are phylogenetically related to the bacteriocin-producing bacteria. These peptides are very potent and are effective at pico- or nanomolar concentrations (Hassan et al., 2012).

Bacteriocins form channels in the target cell membrane, causing low-molecular-weight ions to leak from the cell, leading to collapse of the proton motive force (Dicks et al., 2011; Hassan et al., 2012). Bacteriocins are highly heterogeneous peptides in terms of size, structure and activity. According to a recent classification, bacteriocins produced by Gram-positive bacteria have been divided into two large groups (Chen and Hoover, 2003; Cotter and Ross, 2005);

Class I, lantibiotics, are small peptides with post-translational modifications. Class Ia peptides are small peptides containing 19-38 amino acids. Nisin, which is produced by Lactococcus lactis, is the best known lantibiotic and was the first bacteriocin allowed to be used as a natural preservative in foods. Class Ib peptides are globular peptides that affect the essential enzymes of the target cell.

Class II, non-lanthionines, are small peptides containing 25-60 amino acids; these peptides are non-modified and heatresistant. LAB are mostly producers of class II bacteriocins. Class II peptides are divided into 4 subgroups. Class IIa bacteriocins are known for their anti-listerial activity. These peptides are also called pediocin-like bacteriocins because pediocin was the first peptide in this group to be characterized. Class IIb bacteriocins consist of two peptides, and both peptides are required for activity. Class IIc bacteriocins are cyclic peptides that are covalently bonded at the $\mathrm{N}$ and $\mathrm{C}$ termini. Class IId bacteriocins are linear, single-peptide and non-pediocin-like bacteriocins.

When the characteristics of bacteriocins are taken into consideration, these peptides are thought to be promising therapeutic agents for the control of microbial pathogens, including multidrug-resistant pathogens (Dicks et al., 2011). Some in vivo studies have determined that various bacteriocins inhibit antibiotic-resistant bacteria. For example, mersacidin is produced by the Bacillus sp. HIL-Y85/54728 strain to inhibit methicillin-resistant Staphylococcus aureus strains in mice (Kruszewska et al., 2004). Lacticin 3147, produced by L. lactis subsp. lactis, has been reported to inhibit $S$. aureus, methicillin-resistant $S$. aureus and vancomycin-resistant E. faecalis (VRE) (Galvin et al., 1999). These studies have shown that bacteriocin-based therapeutic approaches contribute to the battle against these pathogens.

Probiotic bacteria (lactobacilli, bifidobacteria and enterococci) are natural producers of bacteriocins. Rea et al. (2010) have shown that bacteriocin-producing probiotics play an important role in the fight against infectious bacteria in the human gastrointestinal tract. Potential medical applications of bacteriocins have been well documented against various systemic urogenital, gastrointestinal, respiratory and skin infections, including infections caused by multidrug-resistant bacteria (Dicks et al., 2011).

Because LAB are accepted as "generally recognized as safe" (GRAS), the bacteriocins produced by the LAB are also accepted as being safe (Abbasiliasi et al., 2017; Macaluso et al., 2016; Yang et al., 2014). Patented applications of nisin and pediocin, either alone or in combination with other hurdle technologies, for the inhibition of various pathogenic or saprophytic bacteria in food have been reported by Cleveland et al. (2001).

Bacteria of the genus Enterococcus belong to the LAB group (von Right and Axelson, 2011). It is known that Enterococcus spp. are components of the microbiota of many fermented foods such as cheeses, olives and other plant products (Giraffa, 2003). High salt and $\mathrm{pH}$ tolerance make these bacteria particularly interesting in terms of their use as starters or co-cultures in food fermentations. On the other hand, enterococci are also associated with hospital-acquired infections. Such pathogens have multiple antibiotic-resistance and virulence factors (Franz et al., 2011; von Right and Axelson, 2011).

In the present study, the antimicrobial activity of the bacteriocin produced by E. faecalis KT11 against some food-borne 
and clinical pathogens, including vancomycin- and/or methicillin-resistant bacteria, was examined. Additionally results of partial purification and characterization studies of bacteriocin reported. To the best of our knowledge, this is the first study about the characterization and partial purification of bacteriocin produced by a lactic acid bacterium (E. faecalis KT11) isolated from Karg1 Tulum cheese, an artisanal cheese produced by traditional methods with natural fermentation.

\section{Materials and Methods}

\section{Cultivation of $E$. faecalis KT11}

The E. faecalis strain KT11 (NCBI accession number: MH746081) used in this study was isolated (from Karg1 Tulum cheese) as a part of our previous project in the Food Microbiology Laboratory of Eskişehir Osmangazi University. API 50CH and API Strep20 test kits (bioMérieux, France) and real-time PCR identification methods were used for species-level identification. E. faecalis KT11 was grown in de Man-Rogosa-Sharpe broth (MRS; Merck, Germany) at $37^{\circ} \mathrm{C}$ for $24 \mathrm{~h}$ and maintained as a frozen stock at $-20^{\circ} \mathrm{C}$ in MRS broth containing $20 \%(\mathrm{v} / \mathrm{v})$ glycerol. E. faecalis $\mathrm{KT} 11$ stock cultures revived in MRS broth and incubated aerobically for $24 \mathrm{~h}$ at $37^{\circ} \mathrm{C}$ three times before use.

\section{Cell-free supernatant (CFS) preparation from E. faecalis KT11}

E. faecalis KT11 was inoculated $(1 \% \mathrm{v} / \mathrm{v})$ into MRS broth and incubated aerobically for $24 \mathrm{~h}$ at $37^{\circ} \mathrm{C}$. Then, the culture was centrifuged at 5,000 rpm for $10 \mathrm{~min}$ at $4^{\circ} \mathrm{C}$ (Sigma-3-16K, UK), and the supernatant was collected. To avoid the inhibitory effects of organic acids and hydrogen peroxide $\left(\mathrm{H}_{2} \mathrm{O}_{2}\right)$, the $\mathrm{pH}$ of the CFS was adjusted to 6.5 with $5 \mathrm{M} \mathrm{NaOH}$, and catalase $(1 \mathrm{mg} / \mathrm{mL})$ was added. The CFS was then filtered through a $0.22-\mu \mathrm{m}$ pore size filter (Millipore, Merck). Catalasefree CFSs were used as the control series.

\section{Antimicrobial spectrum of CFS obtained from E. faecalis KT11}

To determine the antimicrobial potential of the CFS, an agar well diffusion assay (AWDA) was performed. All indicator test strains (30 strains) used in this assay and the collection numbers of these strains are shown Table 1. Indicator test strains were first cultivated in appropriate broth media (MRS broth for LAB and nutrient broth for the other strains; Merck). Final cell density of each indicator strain was adjusted to $10^{6} \mathrm{CFU} / \mathrm{mL}$ using McFarland standard no. 1 (Merck). Then, $100 \mu \mathrm{L}$ of these cultures was inoculated into molten soft MRS/nutrient agar tubes (MRS broth/nutrient broth+agar $(0.7 \% \mathrm{w} / \mathrm{v})$ ). After homogenizing, the inoculated soft agar was rapidly poured onto pre-prepared plates containing MRS/nutrient agar (Merck). After solidification, the soft agar plates were maintained at $4^{\circ} \mathrm{C}$ for $1 \mathrm{~h}$, and then, wells with $8-\mathrm{mm}$ diameters were made with a sterile cork borer. Then, CFS was added into each well $\left(100 \mu \mathrm{L} /\right.$ well), and the plates were incubated for $24 \mathrm{~h}$ at $28^{\circ} \mathrm{C}$ for $P$. aeruginosa, B. cereus and $M$. luteus and $37^{\circ} \mathrm{C}$ for the remaining indicator strains. Then diameter of the inhibition zone around the well was measured (including well diameter).

In this study, all antimicrobial activity measurements were made in duplicate and repeated at least twice.

\section{Characterization of bacteriocin KT11}

The effects of hydrolytic enzymes, heat, $\mathrm{pH}$, surfactants, organic solvents, lyophilization and storage temperature on the stability of bacteriocin KT11 was determined. S. aureus ATCC 25923 was used as indicator test strain to determine the effects of different treatment conditions on the activity of bacteriocin from E. faecalis KT11. 
Table 1. Antimicrobial activity of the CFS obtained from E. faecalis KT11 against indicator bacteria

\begin{tabular}{|c|c|c|c|}
\hline Indicator bacteria & $\begin{array}{l}\text { Inhibition zones } \\
\text { (mm) }\end{array}$ & Indicator bacteria & $\begin{array}{l}\text { Inhibition zones } \\
(\mathrm{mm})\end{array}$ \\
\hline Escherichia coli LMG 8223 & $-b$ & Lactococcus lactis ssp. cremoris NRRL 634 & - \\
\hline Escherichia coli O157 ATCC 35150 & - & Leuconostoc mesenteroides ssp. mes. NRRL 1118 & $15.0 \pm 0.8$ \\
\hline Klebsiella pneumoniae ATCC 13883 & $14.0 \pm 0.8$ & Lactobacillus fermentum NRRL 1840 & - \\
\hline Serratia marcescens NRRL 2544 & $18.0 \pm 0.6$ & Weissella viridescens NRRL 1951 & - \\
\hline Enterobacter aerogenes ATCC 13048 & $15.0 \pm 0.8$ & Enterococcus faecium NRRL 2354 & - \\
\hline Pseudomonas aeruginosa ATCC 2783 & $14.0 \pm 1.0$ & Lactobacillus acidophilus NRRL 4495 & $14.0 \pm 0.8$ \\
\hline Listeria monocytogenes LMG 13305 & $15.0 \pm 0.5$ & Lactobacillus plantarum NRRL 4496 & - \\
\hline Bacillus subtilis NRRL NRS 744 & $15.0 \pm 0.8$ & Staphylococcus epidermidis ${ }^{\mathrm{c}}$ (Anadolu Univ.) & $20.0 \pm 1.4$ \\
\hline Bacillus cereus LMG 8221 & - & Staphylococcus warneri ${ }^{\mathrm{e}}$ (Anadolu Univ.) & $20.0 \pm 1.0$ \\
\hline Micrococcus luteus NRRL 1018 & $16.0 \pm 1.6$ & Staphylococcus aureus ${ }^{\mathrm{e}}$ (Anadolu Univ.) & - \\
\hline Staphylococcus aureus ATCC 25923 & $16.0 \pm 1.8$ & Staphylococcus haemolyticus ${ }^{\mathrm{e}}$ (Anadolu Univ.) & - \\
\hline Streptococcus faecalis NRRL 14617 & $16.0 \pm 0.5$ & Staphylococcus epidermidis ${ }^{\mathrm{e}}$ (Anadolu Univ.) & - \\
\hline Enterococcus faecalis NRRL 29212 & $16.0 \pm 2.1$ & Staphylococcus hominis ${ }^{\mathrm{d}}$ (Anadolu Univ.) & - \\
\hline Lactobacillus pentosus NRRL 227 & - & Staphylococcus sp. ${ }^{\mathrm{c}}$ (clinical isolate) & $15.0 \pm 1.0$ \\
\hline Lactococcus lactis ssp. lactis NRRL 633 & - & Enterococcus sp. ${ }^{\mathrm{d}}$ (clinical isolate) & $17.0 \pm 0.8$ \\
\hline
\end{tabular}

${ }^{a}$ Agar well assay was used and wells ( $8 \mathrm{~mm}$ in diameter) were filled with $100 \mu \mathrm{L} \mathrm{CFS} \mathrm{samples;}{ }^{\mathrm{b}}$ no inhibition; ${ }^{\mathrm{c}}$ methicillin-resistant; ${ }^{\mathrm{d}}$ vancomycinresistant; ${ }^{\mathrm{e}}$ methicillin and vancomycin-resistant.

\section{Effect of hydrolytic enzymes on bacteriocin KT11}

Sensitivity of bacteriocin KT11 to hydrolytic enzymes was determined by treatment with proteinase K, $\alpha$-chymotrypsin, protease, pepsin, trypsin, catalase and $\alpha$-amylase. All enzymes were supplied by Sigma-Aldrich, Germany; the enzymes were diluted (final concentration of $1 \mathrm{mg} / \mathrm{mL}$ ) and then filter sterilized. Each enzyme solution was added to the bacteriocin KT11 samples and incubated $\left(37^{\circ} \mathrm{C}\right.$ for $\left.2 \mathrm{~h}\right)$. Then, the enzymes in the bacteriocin KT11 samples were heat inactivated ( 3 min at $100^{\circ} \mathrm{C}$ ). The $\mathrm{pH}$ of the samples was adjusted to 6.5. Residual antimicrobial activity was monitored by conducting an AWDA as described above. Bacteriocin KT11+buffer and buffer alone served as controls.

\section{Stability of bacteriocin KT11 at different temperatures}

Heat resistance of bacteriocin KT11 was determined by heating the bacteriocin KT11 samples to $60^{\circ} \mathrm{C}, 80^{\circ} \mathrm{C}$, or $100^{\circ} \mathrm{C}(30$ or $60 \mathrm{~min}$ ) or $121^{\circ} \mathrm{C}(15$ or $30 \mathrm{~min})$. Antimicrobial activity was determined by conducting an AWDA. Untreated bacteriocin KT11 was used as a control. Percentage of activity was calculated for each replicate with this formula; \% activity=inhibition zone of the treated sample/inhibition zone of the control sample $\times 100$.

\section{Effect of pH on the stability of bacteriocin KT11}

The $\mathrm{pH}$ of the bacteriocin KT11 samples was adjusted to 2, 3, 4, 5, 6, 7, 8, 9, 10 or 11, and the samples were maintained at $4^{\circ} \mathrm{C}$ for $0,6,12,18$ or $24 \mathrm{~h}$. At specified timepoints, $\mathrm{pH}$ values of samples were re-adjusted to 6.5 and their residual antimicrobial activity were determined. 
The effect of various organic solvents (all from Sigma-Aldrich, Germany) on bacteriocin KT11 was determined by adding chloroform (10\%), propanol (10\%), methanol (10\%), ethyl alcohol (10\%), acetone (10\%), hexane (25\%) or ethyl ether $(25 \%)$ to the samples. Bacteriocin KT11 were incubated at $25^{\circ} \mathrm{C}$ for $1 \mathrm{~h}$ and then evaporated in a vacuum concentrator (Hernández et al., 2005). Untreated bacteriocin KT11 and the organic solvents in MRS broth at the concentrations mentioned above were used as controls.

\section{Effect of surfactants on the stability of bacteriocin KT11}

The effect of surfactants was determined by adding ( $1 \% \mathrm{v} / \mathrm{v})$ ethylenediaminetetraacetic acid (EDTA), sodium dodecyl sulfate (SDS), Triton X-100, Tween 80 or urea (all from Sigma-Aldrich, Germany) to the bacteriocin KT11 samples (Todorov and Dicks, 2005). Untreated bacteriocin KT11 and the surfactants in MRS broth at the concentration mentioned above were used as controls.

\section{Effect of lyophilization and storage temperature on the stability of bacteriocin KT11}

Five milliliters of filter-sterilized bacteriocin KT11 samples were lyophilized (Christ, Alpha 1-4, UK; under 0.0010 mbar at $-80^{\circ} \mathrm{C}$ for $48 \mathrm{~h}$ ) and stored at $4^{\circ} \mathrm{C},-20^{\circ} \mathrm{C}$, and $-80^{\circ} \mathrm{C}$ for 3 months. At timepoints of $1,15,30,60$, and $90 \mathrm{~d}$, the samples were resuspended in the same volume of sterile deionized water, and the residual activity of each sample was tested by an AWDA (Cherif et al., 2003).

\section{Bacteriocin production kinetics of $E$. faecalis KT11}

Five milliliters of an overnight E. faecalis KT11 culture was inoculated into $500 \mathrm{~mL}$ of MRS broth and incubated at $37^{\circ} \mathrm{C}$ for $24 \mathrm{~h}$. At 2-h intervals, $1 \mathrm{~mL}$ samples were taken, and the cell density of each sample was determined $\left(\mathrm{OD}_{600 \mathrm{~nm}}\right)$. At the same sampling time, $10 \mathrm{~mL}$ of sample was used to prepare a CFS. Then serial two-fold dilutions of the CFS were prepared with sterile deionized water. Wells in the S. aureus ATCC 25923-seeded plates were loaded with $95 \mu \mathrm{L}$ of each dilution of the CFS (95 $\mu \mathrm{L} /$ well). Then plates were incubated at $37^{\circ} \mathrm{C}$ for $24 \mathrm{~h}$, and bacteriocin activity (AU/mL) was determined (Jack et al., 1995).

\section{Optimum storage temperature for the bacteriocin producer $E$. faecalis KT11}

E. faecalis KT11 was cultured as described previously and lyophilized. The lyophilized culture samples were stored for 3 months at different temperatures $\left(4^{\circ} \mathrm{C},-20^{\circ} \mathrm{C}\right.$, and $\left.-80^{\circ} \mathrm{C}\right)$. During storage, culture samples were extracted at timepoints of 1 , 15, 30, 60, and $90 \mathrm{~d}$ and inoculated into MRS broth. After incubation, CFSs were prepared as described previously, and then, the antimicrobial activity of bacteriocin KT11 was evaluated by conducting an AWDA.

\section{Protein precipitation with ammonium sulfate}

E. faecalis KT11 was cultured at $37^{\circ} \mathrm{C}$ for $18 \mathrm{~h}$, and bacteriocin $\mathrm{KT} 11$ was obtained as described above. The CFS was gradually saturated in three steps, with final ammonium sulfate concentrations of $40 \%, 60 \%$, and $80 \%$, and incubated overnight at $4^{\circ} \mathrm{C}$, shaking at $100 \mathrm{rpm}$. Protein precipitate was obtained by centrifugation (Hettich, Mikro200R, Germany) at $10,000 \mathrm{rpm}$ at $4^{\circ} \mathrm{C}$ for $1 \mathrm{~h}$ (Pingitore et al., 2007). The precipitate was dissolved in $3 \mathrm{~mL}$ of $0.1 \mathrm{M} \mathrm{KH}_{2} \mathrm{PO}_{4}$ buffer (pH 6.0) and dialyzed overnight against same buffer in SnakeSkin dialysis tubing (3.5 kDa molecular weight cut-off, Thermo Fisher Scientific, USA). The dialysate $(5.5 \mathrm{~mL})$ was collected and stored at $-20^{\circ} \mathrm{C}$ until further use. The amount of protein in the 
CFS, ammonium sulfate precipitate and dialysate was determined by the Bradford method (Bradford, 1976) by using a NanoDrop spectrophotometer at $595 \mathrm{~nm}$ (NanoDrop 2000c, Thermo Fisher Scientific, USA).

\section{Determination of the molecular weight of bacteriocin KT11 and direct activity detection}

Tricine-SDS-PAGE was performed to determine the molecular weight of partially purified bacteriocin KT11 (Schägger and von Jagow (1987). The ultra-low-range molecular weight marker (M.W. 1.06-26.6 kDa, Sigma-Aldrich) was used as a protein standard. A 16\% Tris-tricine gel was prepared for electrophoresis. The amount of protein in the dialysate to be loaded into the gel was calculated as $5 \mu \mathrm{g}$. Dialysate samples were dissolved in tricine loading buffer and loaded into the gel. After electrophoresis, the gel was sliced into two pieces. One piece of the gel was assayed for molecular weight determination of bacteriocin KT11 (Lane M and Lane 1) by staining with Coomasie blue R 250 for $3 \mathrm{~h}$. The other piece of the gel (Lane 2) was not stained and was used for a direct antimicrobial activity assay (overlay method). To remove SDS from the second lane, the gel was washed three times with 1\% Tween 80 for $40 \mathrm{~min}$ (Yamamoto, 2003), transferred into a petri dish, and then overlaid with $15 \mathrm{~mL}$ of soft nutrient agar (seeded with indicator test strain at $10^{6} \mathrm{CFU} / \mathrm{mL}$ ). After incubation at $37^{\circ} \mathrm{C}$ for $24 \mathrm{~h}$, the gel was examined for the presence of an inhibitory zone.

\section{Statistical analysis}

Mean and standard error values of two or three experiments were calculated using Microsoft Excel ${ }^{\circledR}$. One way analysis variance (ANOVA) was performed using PASW-Statistics18-SPSS software (Hong Kong) to determine statistically significant difference (95\% confidence interval) among experimental variables.

\section{Results and Discussion}

\section{Antimicrobial activity spectrum of the CFS}

Enterococcus spp. are classified as LAB and are frequently isolated from cheese samples. These bacteria play important roles in the ripening of cheese and confer the typical taste and aroma to the product (Foulquié Moreno et al., 2006). The E. faecalis KT11 strain used in this study was isolated from an artisanal Tulum cheese produced in Karg1, Turkey. This cheese is produced from raw goat, sheep or cow milk or a mixture of these milks. The E. faecalis KT11 strain was identified in our previous project with classic biochemical and physiological tests and molecular identification techniques with speciesspecific primers based on 16S rDNA (Kunduhoglu et al., 2012). LAB can produce inhibitory substances such as bacteriocins, $\mathrm{H}_{2} \mathrm{O}_{2}$ and organic acids in growth media (Lahtinen et al., 2011). Therefore, to eliminate the inhibitory effects of $\mathrm{H}_{2} \mathrm{O}_{2}$ and organic acids, the CFS of E. faecalis KT11 was first treated with catalase, and the $\mathrm{pH}$ of the CFS was adjusted to 6.5; then, the CFS was used in antimicrobial activity tests. Catalase-free CFSs served as a control series. The antimicrobial spectrum of the CFS was determined by an AWDA against indicator test bacteria.

It is known that most bacteriocins inhibit Gram-positive bacteria, while the outer lipopolysaccharide membrane of Gramnegative bacteria acts as natural barrier against the entry of bacteriocins into the cell (Gyawali and Ibrahim, 2014; Yildirim et al., 2014). However, in our study, the CFS obtained from E. faecalis KT11 exhibited antimicrobial activity against 16 of the 30 indicator bacteria, including Gram-negative bacteria, with inhibition zones ranging from 14 to $20 \mathrm{~mm}$ (Table 1). Catalasefree CFSs exhibited the same activity against the indicator bacteria. The CFS inhibited 12 of the 24 Gram-positive indicator bacteria, including L. monocytogenes, S. aureus ATCC 25923 and the spore-forming Bacillus subtilis, with inhibition zones 
ranging from 14 to $20 \mathrm{~mm}$. Similar to our results, Xi et al. (2017) reported that cell-free extracts of E. faecalis TG2 isolated from tofu showed antimicrobial activity against Gram-positive indicator bacteria such as L. monocytogenes, L. ivanovii, L. innocua, E. faecalis, Lactobacillus sp., Pediococcus sp., and Leuconostoc sp. In another study, bacteriocin obtained from a $E$. faecium strain isolated from donkey milk exhibited antimicrobial activity against L. monocytogenes, S. aureus and Bacillus cereus (Aspri et al., 2017). Vimont et al. (2017) reported that E. faecium LCW 44 exhibited antimicrobial activity against Clostridium, Listeria, Staphylococcus, and Lactobacillus but not against Gram-negative bacteria. Sensitivity of Listeria spp. against bacteriocins of enterococci can be explained by the close phylogenetic relationship between Listeria and enterococci (Foulquié Moreno et al., 2006).

The CFS of E. faecalis KT11 showed antimicrobial activity against 4 of the 6 Gram-negative indicator bacteria, namely, $P$. aeruginosa, K. pneumoniae, S. marcescens and E. aerogenes, with inhibition zones ranging from 14 to $18 \mathrm{~mm}$. Similar to our results, Perumal and Venkatasen (2017) obtained enterocin CV7 from E. faecalis CV7 and reported that this bacteriocin exhibited broad antimicrobial activity against both Gram-positive bacteria (L. monocytogenes and S. aureus) and Gramnegative bacteria (Salmonella sp., S. thypi, S. enterica, E. coli and Vibrio fischeri). Abriouel et al. (2005) reported that two enterocins obtained from E. faecalis inhibited E. coli and Shigella sonnei.

The CFS of E. faecalis KT11 inhibited the growth of methicillin- and/or vancomycin-resistant test bacteria, with inhibition zones ranging from 15 to $20 \mathrm{~mm}$. Similarly, Phumisantiphong et al. (2017) reported that a bacteriocin from E. faecalis EF 478 exhibited antimicrobial activity against $E$. faecalis and E. faecium. Additionally, they reported that this bacteriocin has an inhibitory effect on 28 of the 68 (41.1\%) multidrug-resistant enterococci and vancomycin-resistant enterococci. Saelim et al. (2015) also reported that enterocin CE5-1 from E. faecium CE5-1 inhibited some vancomycin-resistant strains of E. faecalis, E. faecium, and E. gallinarum. In our study, the test strains that were most susceptible to CFS were found to be S. epidermidis (methicillin-resistant), S. warneri (methicillin- and vancomycin-resistant), S. marcescens and Enterococcus sp. (vancomycin-resistant).

\section{Characterization of the bacteriocin produced by E. faecalis KT11}

Effect of hydrolytic enzymes on the stability of the bacteriocin: LAB synthesize antimicrobial substances, and many of these agents are proteinaceous bacteriocins, while others are non-protein agents such as lactic acid, $\mathrm{H}_{2} \mathrm{O}_{2}$ and diacetyl (Lahtinen et al., 2011). In our study, to prove the proteinaceous nature of the antimicrobial compound(s), the CFS was treated with proteolytic enzymes, and then, residual bacteriocin activity was determined against S. aureus ATCC 25923, P. aeruginosa and M. luteus test strains. The residual activity of the CFS decreased by $40 \%$ after pepsin treatment, and the activity of the CFS was found to be $100 \%$ sensitive to trypsin, $\alpha$-chymotrypsin, protease and proteinase K, suggesting the proteinaceous nature of the compound (Table 2). Therefore, the CFS from E. faecalis KT11 was referred to as "bacteriocin KT11" in the rest of this text. Additionally, the CFS retained its activity after treatment with catalase and $\alpha$-amylase. Similar findings have been reported in studies with LAB, where bacteriocin activity was totally abolished after treatment with various proteolytic enzymes (Aspri et al., 2017; Chen et al., 2016; Xi et al., 2017; Yanagida et al., 2005). Isleroglu et al. (2011) determined that enterocin KP, obtained from E. faecalis $\mathrm{KP}$, was stable after treatment with pepsin. In a study by Gupta et al. (2016) the supernatant of E. hirae LD3 lost antimicrobial activity upon treatment with proteolytic enzymes; however, this supernatant remained active after catalase and $\alpha$-amylase treatment, suggesting that $\mathrm{H}_{2} \mathrm{O}_{2}$ and carbohydrate moieties played no role in the activity.

\section{Effect of different heat treatments on the stability of bacteriocin KT11}

Bacteriocin KT11 samples were subjected to different temperatures $\left(60^{\circ} \mathrm{C}, 80^{\circ} \mathrm{C}, 100^{\circ} \mathrm{C}\right.$, and $\left.121^{\circ} \mathrm{C}\right)$ for 30 min, and the 
Table 2. Effect of hydrolytic enzymes (final concentration of $1 \mathrm{mg} / \mathrm{mL}$ ) on antimicrobial activity of the CFS obtained from E. faecalis KT11

\begin{tabular}{|c|c|c|c|}
\hline \multirow{2}{*}{ Treatments } & \multicolumn{3}{|c|}{ Inhibition zone diameter $(\mathrm{mm})^{\mathrm{a}}$} \\
\hline & S. aureus ATCC 25923 & P. aeruginosa ATCC 2783 & M. luteus NRRL 1018 \\
\hline CFS (control) & $15.0 \pm 0.5$ & $18.0 \pm 1.0$ & $15.0 \pm 0.8$ \\
\hline Trypsin+CFS & $-b$ & - & - \\
\hline Trypsin+buffer & - & - & - \\
\hline Pepsin+CFS & $9.0 \pm 1.4$ & $10.0 \pm 2.9$ & $10.0 \pm 1.8$ \\
\hline Pepsin+buffer & - & - & - \\
\hline$\alpha$-Chymotrypsin + CFS & - & - & - \\
\hline$\alpha$-Chymotrypsin+buffer & - & - & - \\
\hline Protease+CFS & - & - & - \\
\hline Protease+buffer & - & - & - \\
\hline Proteinase $\mathrm{K}+\mathrm{CFS}$ & - & - & - \\
\hline Proteinase $\mathrm{K}+$ buffer & - & - & - \\
\hline Catalase + CFS & $15.0 \pm 0.8$ & $16.0 \pm 0.5$ & $16.0 \pm 0.5$ \\
\hline Catalase+buffer & - & - & - \\
\hline$\alpha$-Amylase + CFS & $15.0 \pm 1.0$ & $16.0 \pm 1.6$ & $16.0 \pm 1.0$ \\
\hline$\alpha$-Amylase+buffer & - & - & - \\
\hline
\end{tabular}

${ }^{a}$ Agar well assay was used and wells ( $8 \mathrm{~mm}$ in diameter) were filled with $100 \mu \mathrm{L}$ CFS samples; ${ }^{\mathrm{b}}$ no inhibition.

residual antimicrobial activity against $S$. aureus ATCC 25923 was assessed by an AWDA. The results showed that bacteriocin KT11 was thermostable even at $121^{\circ} \mathrm{C}$ for $30 \mathrm{~min}$ (Fig. 1). Effect of the different treatment temperatures towards to stability of KT11 was not statistically significant $(p>0.05)$. However, bacteriocin KT11 lost $8.3 \%-11.1 \%$ of its activity after the heat treatments when compared with controls $(p<0.05)$.

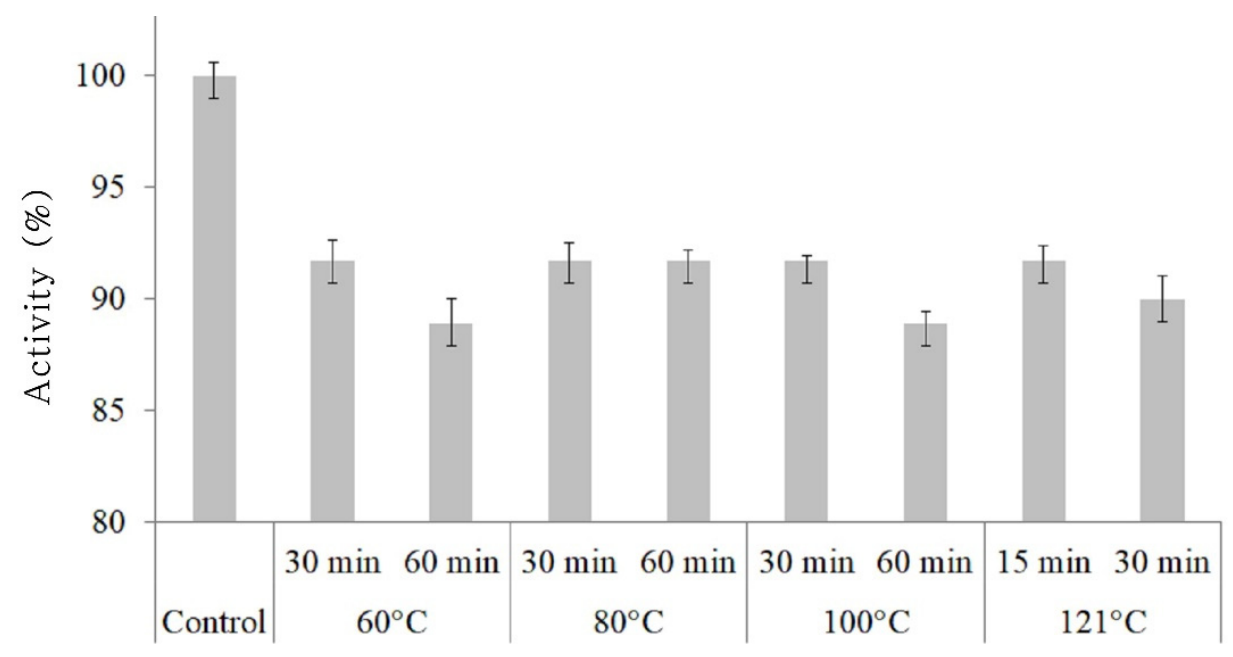

Fig. 1. Effect of heat treatments on bacteriocin KT11 stability. Heat resistance of bacteriocin KT11 was determined by heating the bacteriocin $\mathrm{KT} 11$ samples to $60^{\circ} \mathrm{C}, 80^{\circ} \mathrm{C}, 100^{\circ} \mathrm{C}$, and $121^{\circ} \mathrm{C}$. Untreated bacteriocin $\mathrm{KT} 11$ samples were used as a control. Residual antimicrobial activity was determined by AWDA and S. aureus ATCC 25923 was used as indicator bacteria. Then percentage of activity was calculated (\% activity=inhibition zone of the treated sample/inhibition zone of the control samplex100). 
Similar to our findings, enterocins from E. durans (Du et al., 2017; Yanagida et al., 2005), E. faecium (Kumar et al., 2010), E. hirae (Gupta et al., 2016) and E. faecalis (Khalkhali and Mojgani, 2017; Xi et al., 2017) were reported to be stable for 10$20 \mathrm{~min}$ at $121^{\circ} \mathrm{C}$. It was also determined that some enterocins were stable at lower temperatures. For example, Cocolin et al. (2007) reported that a bacteriocin from E. faecium M241 remained completely stable after a 10-min heat treatment at $100^{\circ} \mathrm{C}$, while the activity decreased at higher temperatures. Phumisantiphong et al. (2017) reported that a bacteriocin that they obtained from E. faecalis EF 478 remained completely stable after heat treatment at $60^{\circ} \mathrm{C}$ for $1 \mathrm{~h}$, but that activity decreased at $80^{\circ} \mathrm{C}$ for $1 \mathrm{~h}$ and at higher temperatures. Braïek et al. (2017) reported that the heat tolerance limit of the inhibitory substance obtained from the E. lactis $\mathrm{Q} 1$ strain was $60^{\circ} \mathrm{C} / 30$ min or $100^{\circ} \mathrm{C} / 15 \mathrm{~min}$.

Therefore, based on its proteinaceous nature and thermostability at $121^{\circ} \mathrm{C}$ for $30 \mathrm{~min}$, bacteriocin $\mathrm{KT} 11$ could be classified as a heat-stable bacteriocin.

\section{Effect of pH on the stability of bacteriocin KT11}

The stability of bacteriocin KT11 at different pH levels was studied between $\mathrm{pH} 2$ and 11 for $24 \mathrm{~h}$. All the bacteriocin KT11 samples treated with different $\mathrm{pH}$ levels remained stable and showed antimicrobial activity against the indicator $S$. aureus ATCC 25923 strain. Effect of the different pH levels towards to stability of KT11 was not statistically significant $(p>0.05)$. Maximum bacteriocin activity was recorded at $\mathrm{pH} 2-5$. However, $5.9 \%-10 \%$ of the activity of bacteriocin KT11 was lost at alkaline $\mathrm{pH}$ levels (Fig. 2). Similarly, it has been reported that bacteriocins of E. faecium LR/6 (Kumar et al., 2010), E. faecalis CV7 (Perumal and Vankatesen, 2017), and E. hirae LD3 (Gupta et al., 2016) were stable in the pH ranges 2-6, 4-6 and 2-6, respectively. Du et al. (2017) reported that the anti-listerial activity of a bacteriocin obtained from $E$. durans 152 was completely retained in the $\mathrm{pH}$ range of $2-8$.

Bacteriocins that are stable over a wide $\mathrm{pH}$ range have a significant advantage in terms of their potential use as biopreservatives in food products and fermented foods (Franz et al., 1996). Therefore, bacteriocin KT11 has promising potential for use as a preservative in foods of a very wide $\mathrm{pH}$ range.

\section{Effect of organic solvents on the stability of bacteriocin KT11}

The activity of bacteriocin KT11 samples treated with chloroform, methanol, ethanol, hexane or acetone decreased

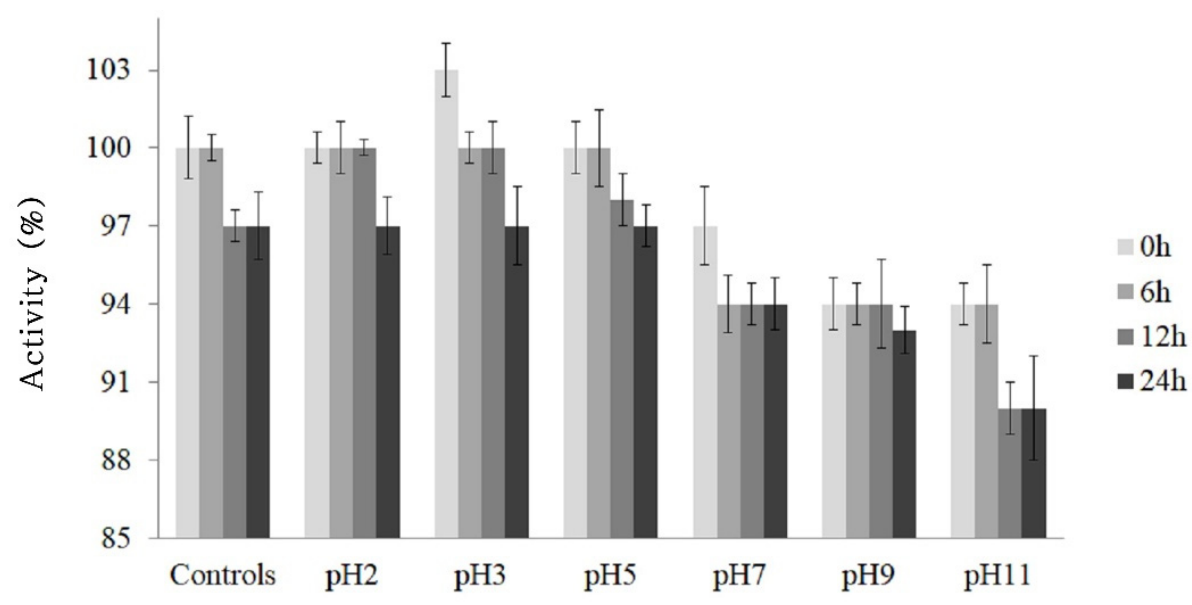

Fig. 2. Stability of bacteriocin KT11 at different pH levels. The pH of the bacteriocin KT11 samples was adjusted and the samples were maintained at $4^{\circ} \mathrm{C}$ for $0,6,12,18$ or $24 \mathrm{~h}$. Untreated bacteriocin $\mathrm{KT} 11$ was used as a control. Their residual antimicrobial activities were determined by AWDA and S. aureus ATCC 25923 was used as indicator bacteria. 
approximately $8 \%-13 \%$ (Fig. 3). Bacteriocin KT11 was completely stable after other solvent treatments. Similar to our findings, it has been previously reported that enterocins remain completely stable after treatment with organic solvents (Isleroglu et al., 2011; Perumal and Vankatesen, 2017). The stability of bacteriocins after treatment with solvents proves that bacteriocins do not have lipid moieties (Yildirim et al., 2014). This finding is also important because many organic solvents are used in bacteriocin purification from supernatants (Aspri et al., 2017).

\section{Effect of surfactants on the stability of bacteriocin KT11}

Bacteriocin KT11 samples were treated with various surfactants at $37^{\circ} \mathrm{C}$ for $180 \mathrm{~min}$, and residual antimicrobial activities were determined. Overall, it was observed that the activity against S. aureus ATCC 25923 was completely (100\%) preserved after these treatments. Similar to our findings, it has been previously reported that enterocins remain stable after treatment with surfactants (Isleroglu et al., 2011; Kumar et al., 2010; Perumal and Vankatesen, 2017).

\section{Growth kinetics and bacteriocin KT11 production}

E. faecalis KT11 was cultured for $24 \mathrm{~h}$, and aliquots were obtained at regular intervals. At each sampling timepoint, the bacteriocin activity (AU/mL) against S. aureus ATCC 25923 and the optical density of the CFS was determined (Fig. 4). Bacteriocin KT11 production started during the early exponential phase, and the bacteriocin activity was determined to be 22 $\mathrm{AU} / \mathrm{mL}$. The maximum bacteriocin activity $(178 \mathrm{AU} / \mathrm{mL})$ was observed between the late exponential and early stationary growth phases (18-22 $\mathrm{h}$ of incubation), and the bacteriocin activity decreased after $22 \mathrm{~h}$. The maximum cell count was observed after 20-24 h of incubation. Extended growth did not lead to higher levels of bacteriocin activity. In some studies, similar growth and enterocin production kinetics were reported for E. faecalis MR99 (Sparo et al., 2006), E. faecium MMT21 strains (Ghrairi et al., 2008) and E. lactis Q1 (Braïek et al. (2017). It has been thought that decrease in bacteriocin activity might be due to digestion of the antimicrobial compounds by proteases released from the cells, protein aggregation, adsorption to cell surface or feedback regulation (Todorov and Dicks, 2006; Gong et al., 2010).

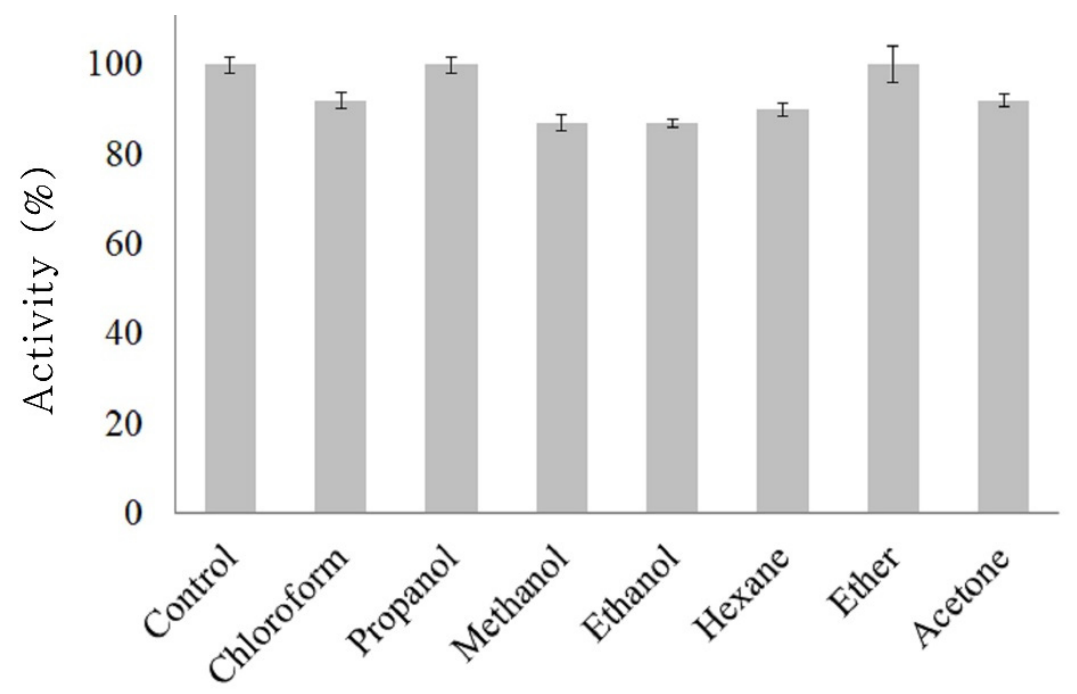

Fig. 3. Effect of organic solvents on bacteriocin stability. The effect of various organic solvents on bacteriocin KT11 activity was determined by adding chloroform, propanol, methanol, ethyl alcohol, acetone, hexane or ethyl ether to the bacteriocin KT11 samples. Untreated bacteriocin KT11 was used as a control. Their residual antimicrobial activities were determined by AWDA and S. aureus ATCC 25923 was used as indicator bacteria. 


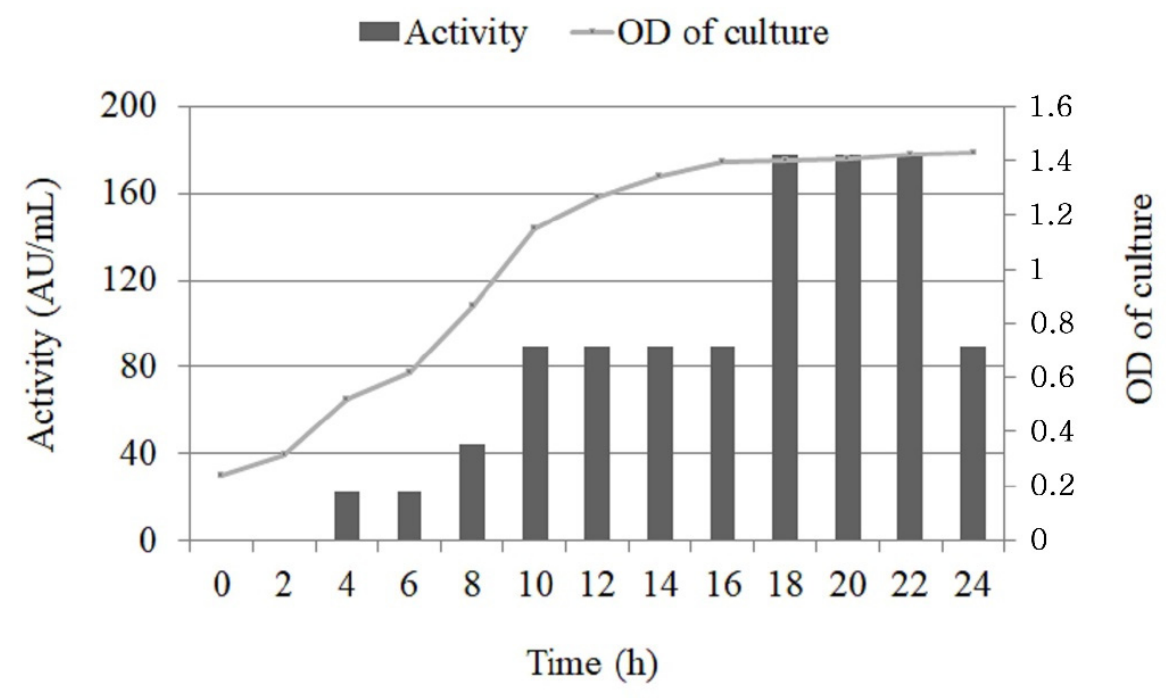

Fig. 4. Production of bacteriocin KT11 during growth of $E$. faecalis KT11 in MRS broth and activity of bacteriocin KT11. Growth of $E$. faecalis KT11 was determined spectrofotometrically (OD $600 \mathrm{~nm}$ ). While line in the graph indicates the optic density (OD) of E. faecalis KT11 culture, bars indicate activity $(\mathrm{AU} / \mathrm{mL})$ of bacteriocin KT11. Antimicrobial activity was determined by AWDA for each sampling time, S. aureus ATCC 25923 was used as indicator bacteria.

\section{Optimum storage temperature for lyophilized bacteriocin KT11}

For potential application of bacteriocin KT11, it has to be produced on a large scale and must be properly concentrated and stocked without losing antimicrobial activity during storage. For this reason, bacteriocin KT11 was lyophilized and stored at different temperatures for $90 \mathrm{~d}$, and the residual antimicrobial activity was determined. Although the antimicrobial activity of lyophilized bacteriocin KT11 stored at $4^{\circ} \mathrm{C}$ was slightly reduced $(p>0.05), 98 \%-100 \%$ of the activity was preserved at the other storage temperatures $\left(-20^{\circ} \mathrm{C}\right.$ and $\left.-80^{\circ} \mathrm{C}\right)$ after 90 days (Fig. 5). Therefore, lyophilized bacteriocin $\mathrm{KT} 11$ can be stored at $-20^{\circ} \mathrm{C}$ and $-80^{\circ} \mathrm{C}$ for at least 90 days without loss of activity. Similar studies have shown that enterocins from E. faecalis (Phumisantiphong et al., 2017) and E. faecalis KP (Isleroglu et al., 2011) did not lose their activities at $4{ }^{\circ} \mathrm{C}$ for 6 months $/-20^{\circ} \mathrm{C}$ for 1 year and $-20^{\circ} \mathrm{C} /-80^{\circ} \mathrm{C}$ for 2 months, respectively. Kumar et al. (2010) reported that an enterocin from E. faecium LR/6 retained complete activity after one year at $4^{\circ} \mathrm{C} /-20^{\circ} \mathrm{C}$.

\section{Partial purification and molecular weight determination of bacteriocin KT11}

To purify the antimicrobial protein, the CFS $(50 \mathrm{~mL})$ was gradually saturated in three steps with ammonium sulfate at final concentrations of $40 \%, 60 \%$, and $80 \%$. Then, the ammonium sulfate precipitate was dissolved in $3 \mathrm{~mL}$ of $0.1 \mathrm{M} \mathrm{K}_{2} \mathrm{HPO}_{4}$ buffer (pH 6.0), desalted by using 3.5-kDa cut-off dialysis membrane and separated by Tris-tricine-SDS-PAGE. The amount of protein in the CFS at specific purification stages was determined by the Bradford method. S. aureus ATCC 25923 was used to test bacteriocin activity at each purification level of bacteriocin KT11 (Table 3). It was determined that the activity increased as the purification steps increased. While bacteriocin activity was $178 \mathrm{AU} / \mathrm{mL}$ in the CFS, the activity was 711 $\mathrm{AU} / \mathrm{mL}$ in dialysate.

Tris-Tricine SDS-PAGE was performed to determine the molecular weight of partially purified bacteriocin KT11. The amount of protein in the dialysate to be loaded into the gel was calculated to be $5 \mu \mathrm{g}$, and the dialysate samples were dissolved in tricine loading buffer. After electrophoresis, the gel was sliced into two pieces. The marker lane (M) and the first lane (lane 1) of gel were assayed for molecular weight determination of bacteriocin KT11 by staining with Coomassie blue. 


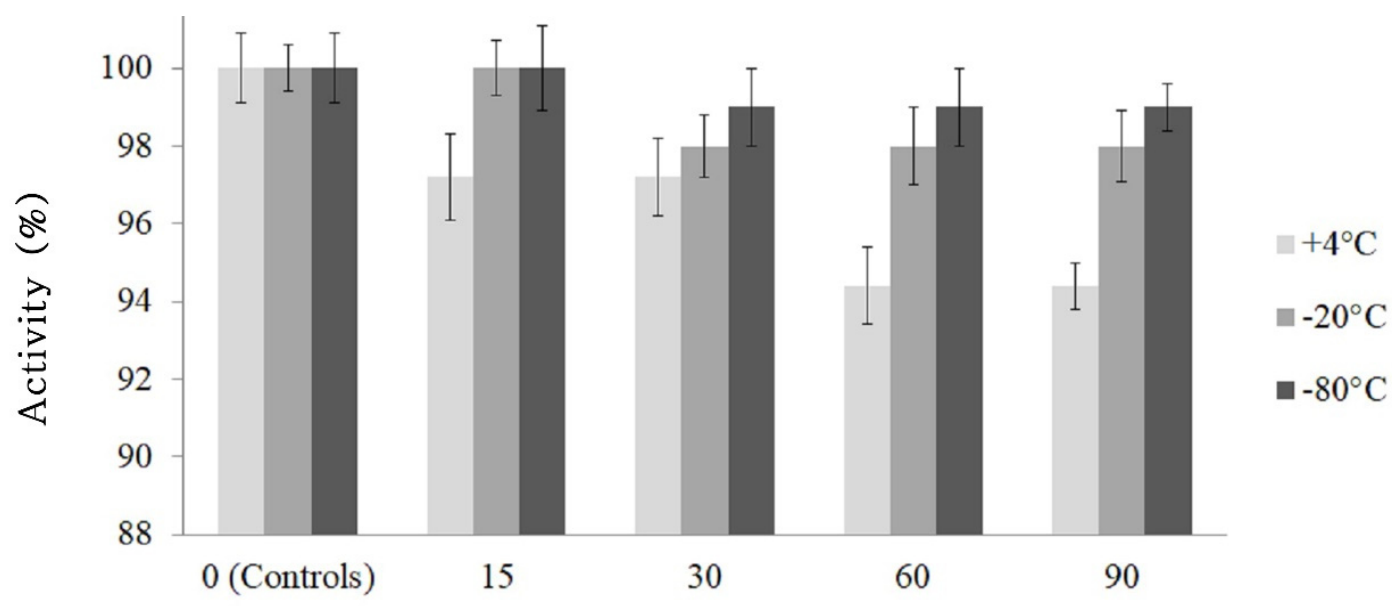

Storage time (days)

Fig. 5. Antimicrobial activity of lyophilized bacteriocin KT11 stored at different temperatures. Lyophilized bacteriocin KT11 samples were stored at $4^{\circ} \mathrm{C},-20^{\circ} \mathrm{C}$, and $-80^{\circ} \mathrm{C}$ for 3 months. During storage, at timepoints of $1,15,30,60$, and $90 \mathrm{~d}$, samples were taken, resuspended in sterile deionized water and their residual antimicrobial activities were determined by AWDA, S. aureus ATCC 25923 was used as indicator bacteria.

Table 3. Amount of protein in the CFS obtained from E. faecalis KT11 and bacteriocin activity of CFS against S. aureus ATCC 25923 at various purification stages

\begin{tabular}{|c|c|c|c|c|c|c|c|c|}
\hline Purification stages & $\begin{array}{l}\text { Volume } \\
(\mathrm{mL})\end{array}$ & $\begin{array}{l}\text { Protein } \\
(\mathrm{mg} / \mathrm{mL})\end{array}$ & $\begin{array}{l}\text { Total protein }{ }^{\mathrm{a}} \\
\text { (mg) }\end{array}$ & $\begin{array}{l}\text { Activity } \\
\text { (AU/mL) }\end{array}$ & $\begin{array}{l}\text { Total activity } \\
\text { (AU) }\end{array}$ & $\begin{array}{l}\text { Specific } \\
\text { activity }^{\mathrm{d}} \\
(\mathrm{AU} / \mathrm{mg})\end{array}$ & $\begin{array}{l}\text { Purification } \\
\text { factor }^{\mathrm{e}}\end{array}$ & $\begin{array}{c}\text { Recovery }^{\mathrm{f}} \\
(\%)\end{array}$ \\
\hline CFS & 50.0 & 0.3286 & 16.4300 & 178 & 8,900 & 541.69 & 1.0 & 100 \\
\hline $\begin{array}{l}\text { Ammonium sulfate } \\
\text { precipitation }\end{array}$ & 3.0 & 0.0507 & 0.1520 & 711 & 2,133 & $14,014.45$ & 25.87 & 23.96 \\
\hline Dialysis & 2.0 & 0.0498 & 0.09976 & 711 & 1,422 & $14,254.21$ & 26.31 & 15.97 \\
\hline
\end{tabular}

${ }^{a}$ Total protein: Amount of protein determined by the Bradford method $\times$ total volume $(\mathrm{mL})$.

${ }^{\mathrm{b}}$ Activity units (AU/mL): Reciprocal of the highest dilution $\times 1,000 /$ volume of bacteriocin added.

c Total activity (AU): Activity unit $\times$ total volume $(\mathrm{mL})$.

${ }^{\mathrm{d}}$ Specific activity (AU/mg): Total activity of the subsequent purification step/total protein of the same step.

${ }^{\text {e }}$ Purificaton factor: Specific activity of subsequent purification step/specific activity of the crude preparation.

${ }^{\mathrm{f}}$ Recovery (\%): Total activity of the subsequent purification step/total activity of the crude preparation $\times 100$.

The second lane (lane 2) of gel was not stained and was used for a direct antimicrobial activity assay (overlay method) and examined for the presence of an inhibitory zone. One antimicrobial peptide band was observed on the overlaid SDS-PAGE gel (Fig. 6). Based on the SDS-PAGE analysis, it can be concluded that the peptide responsible for antimicrobial activity has a molecular size of $\sim 3.5 \mathrm{kDa}$. The molecular weights of enterocins obtained from some Enterococcus strains have been reported to be as follows: $\sim 6.0 \mathrm{kDa}$ from E. faecium LR/6 (Kumar et al., 2010), $5.8 \mathrm{kDa}$ from E. faecalis KP (Isleroglu et al., 2011), $5 \mathrm{kDa}$ from E. durans (Du et al., 2017) and $4.829 \mathrm{kDa}$ from E. faecalis CV7 (Perumal and Venkatasen, 2017). Yanagida et al. (2005) identified two peptides with antimicrobial activity from E. durans L28-1 strain that had molecular weights of 2.5 and $3.4 \mathrm{kDa}$.

\section{Conclusion}

The bacteriocin obtained from E. faecalis KT11 had a broad antimicrobial spectrum, and inhibited foodborne pathogens 


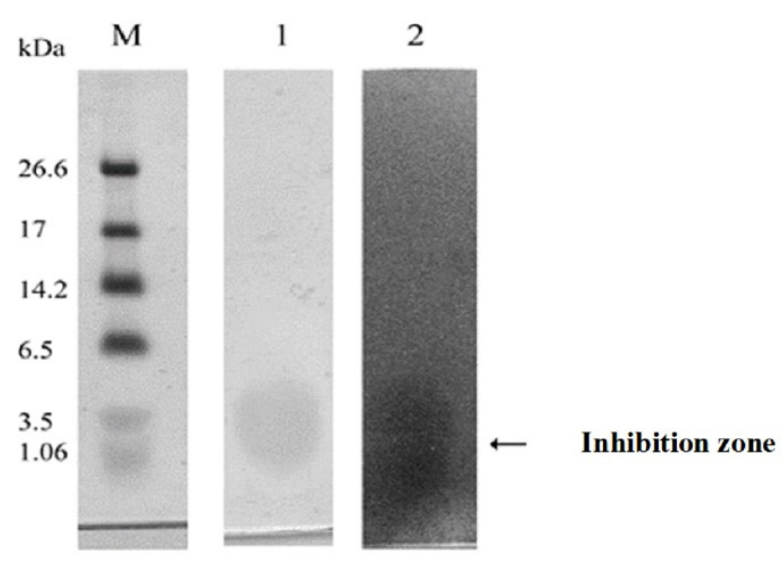

Lane M: Coomassie-blue-stained marker.

Lane 1: Coomassie-blue-stained bacteriocin (dialysate).

Lane 2: Gel overlaid with soft agar inoculated with

S. aureus (overlay method).

Fig. 6. Tricine-SDS-PAGE analysis and direct antimicrobial activity assay of the partially purified bacteriocin KT11 (Lane M; marker, Lane 1; partially purified bacteriocin KT11, Lane 2; gel overlaid with soft nutrient agar seeded with S. aureus ATCC $25923,10^{6}$ CFU/mL).

and vancomycin- and/or methicillin-resistant bacteria. The sensitivity of the CFS to proteolytic enzymes demonstrated the proteinaceous nature of the antimicrobial compound. One peptide band that exhibited antimicrobial activity, with a $\sim 3.5 \mathrm{kDa}$ molecular weight, was identified after tricine-SDS-PAGE analysis. Therefore, the partially purified substance was referred to as "bacteriocin KT11". Bacteriocin KT11 was highly heat-stable $\left(121^{\circ} \mathrm{C}\right.$ for $\left.30 \mathrm{~min}\right)$ and maintained its activity in a $\mathrm{pH}$ range from 2.0 to 11.0. Additionally, bacteriocin KT11 was stable after treatment with some surfactants and organic solvents. Moreover, the activity of lyophilized bacteriocin KT11 was stable after three months of storage at $-20^{\circ} \mathrm{C}$ and $-80^{\circ} \mathrm{C}$.

In conclusion, due to its broad antimicrobial spectrum and stability at high temperatures and over a wide $\mathrm{pH}$ range, bacteriocin KT11 is thought to be a potential efficient bio-preservative in various food products. Furthermore, the fact that bacteriocin KT11 is effective against the drug-resistant pathogens used in this study makes it a promising antimicrobial agent in combating multidrug-resistant pathogens. The utilization of bacteriocin KT11 alone or in combination with conventional antibiotics may be an effective therapeutic option for the treatment of multidrug-resistant clinical pathogens. However, in future studies, bacteriocin KT11 should be purified and identified. In addition, the antimicrobial effectiveness of bacteriocin KT11 should be evaluated in vivo.

\section{Acknowledgements}

This study was supported by the Scientific Research Projects Commission of Eskisehir Osmangazi University (Project number: 2007-19027 and 201519D18).

\section{References}

Abbasiliasi S, Tan JS, Ibrahim TAT, Bashokouh F, Ramakrishnan NR, Mustafa S, Ariff AB. 2017. Fermentation factors 
influencing the production of bacteriocins by lactic acid bacteria: A review. RSC Adv 7:29395-29420.

Abriouel H, Lucas R, Omar NB, Valdivia E, Maqueda M, Martínez-Canãmero M, Gálvez A. 2005. Enterocin AS-48RJ: A variant of enterocin AS-48 chromosomally encoded by Enterococcus faecium RJ16 isolated from food. Syst Appl Microbiol 28:383-397.

Aspri M, O'Connor PM, Field D, Cotter PD, Ross P, Hill C, Papademas P. 2017. Application of bacteriocin-producing Enterococcus faecium isolated from donkey milk, in the bio-control of Listeria monocytogenes in fresh whey cheese. Int Dairy J 73:1-9.

Bradford MM. 1976. A rapid and sensitive method for quantitation of microgram quantities of protein utilizing the principle of protein-dye-binding. Anal Biochem 72:248-254.

Braïek OB, Ghomrassi H, Cremonesi P, Morandi S, Fleury Y, Chevalier PL, Hani K, Hadj OB, Ghrairi T. 2017. Isolation and characterisation of an enterocin P-producing Enterococcus lactis strain from a fresh shrimp (Penaeus vannamei). Antonie van Leeuwenhoek 110:771-786.

Chen H, Hoover DG. 2003. Bacteriocins and their food applications. Comp Rev Food Sci Food Saf 2:82-100.

Chen YS, Wu HC, Yu CR, Chen ZY, Lu YC, Yanagida F. 2016. Isolation and characterization of lactic acid bacteria from XiGua-Mian (fermented watermelon), a traditional fermented food in Taiwan. Ital J Food Sci 28:9-14.

Cherif A, Chehimi S, Limem F, Hansen BM, Hendriksen NB, Daffonchio D, Boudabous A. 2003. Detection and characterization of the novel bacteriocin entomocin 9, and safety evaluation of its producer, Bacillus thuringiensis ssp. entomocidus HD9. J Appl Microbiol 95:990-1000.

Cleveland J, Montville TJ, Nes IF, Chikindas ML. 2001. Bacteriocins: Safe, natural antimicrobials for food preservation. Int J Food Microbiol 71:1-20.

Cocolin L, Foschino R, Comi G, Fortina MG. 2007. Description of the bacteriocins produced by two strains of Enterococcus faecium isolated from Italian goat milk. Food Microbiol 24:752-758.

Cotter PD, Hill C, Ross RP. 2005. Bacteriocins: Developing innate immunity for food. Nat Rev Microbiol 3:777-788.

Dicks LMT, Heunis TDJ, van Staden DA, Brand A, Noll KS, Chikindas ML. 2011. Medical and personal care applications of bacteriocins produced by lactic acid bacteria. In Prokaryotic antimicrobial peptides: From genes to applications. Drider D, Rebuffat S (ed). Springer-Verlag, New York, USA. pp 391-421.

Du L, Liu F, Zhao P, Zhao T, Doyle MP. 2017. Characterization of Enterococcus durans 152 bacteriocins and their inhibition of Listeria monocytogenes in ham. Food Microbiol 68:97-103.

Foulquié Moreno MR, Sarantinopoulos P, Tsakalidou E, De Vuyst L. 2006. The role and application of enterococci in food and health. Int J Food Microbiol 106:1-24.

Franz CMAP, Schillinger U, Holzapfel WH. 1996. Production and characterization of enterocin 900, a bacteriocin produced by Enterococcus faecium BFE 900 from black olives. Int J Food Microbiol 29:255-270.

Franz CMAP, Huch M, Abriouel H, Holzapfel W, Gálvez A. 2011. Enterococci as probiotics and their implications in food safety. Int J Food Microbiol 151:125-140.

Galvin M, Hill C, Ross RP. 1999. Lacticin 3147 displays activity in buffer against Gram-positive bacterial pathogens which appear insensitive in standard plate assays. Lett Appl Microbiol 28:355-358.

Ghrairi T, Frere J, Berjeaud JM, Manai M. 2008. Purification and characterization of bacteriocins produced by Enterococcus faecium from Tunisian Rigouta cheese. Food Control 19:162-169.

Giraffa G. 2003. Functionality of enterococci in dairy products. Int J Food Microbiol 88:215-222. 
Gong HS, Meng XC, Wang H. 2010. Plantaricin MG active against Gram-negative bacteria produced by Lactobacillus plantarum KLDS1.0391 isolated from "Jiaoke", a traditional fermented cream from China. Food Control 21:89-96.

Gupta A, Tiwari SK, Netrebov V, Chikindas ML. 2016. Biochemical properties and mechanism of action of enterocin LD $_{3}$ purified from Enterococcus hirae $\mathrm{LD}_{3}$. Probiotics Antimicrob Proteins 8:161-169.

Gyawali R, Ibrahim SA. 2014. Natural products as antimicrobial agents. Food Control 46:412-429.

Hassan M, Kjos M, Nes IF, Diep DB, Lotfipour F. 2012. Natural antimicrobial peptides from bacteria: Characteristics and potential applications to fight against antibiotic resistance. J Appl Microbiol 113:723-736.

Hernández D, Cardell E, Zárate V. 2005. Antimicrobial activity of lactic acid bacteria isolated from Tenerife cheese: initial characterization of plantaricin TF711, a bacteriocin-like substance produced by Lactobacillus plantarum TF711. J Appl Microbiol 99:77-84.

Isleroglu H, Yıldırım Z, Tokatlı M, Oncul N, Yıldırım M. 2011. Partial characterisation of enterocin KP produced by Enterococcus faecalis KP, a cheese isolate. Int J Dairy Technol 65:90-97.

Jack RW, Tagg JR, Ray B. 1995. Bacteriocins of Gram positive bacteria. Microbiol Rev 59: 171-200.

Khalkhali S, Mojgani N. 2017. Bacteriocinogenic potential and virulence traits of Enterococcus faecium and E. faecalis isolated from human milk. Iran J Microbiol 9:224-233.

Kruszewska D, Sahl HG, Bierbaum G, Pag U, Hynes SO, Ljungh Å. 2004. Mersacidin eradicates methicillin-resistant Staphylococcus aureus (MRSA) in a mouse rhinitis model. J Antimicrob Chemother 54:648-653.

Kumar M, Tiwari SK, Srivastava S. 2010. Purification and characterization of enterocin LR/6, a bacteriocin from Enterococcus faecium LR/6. Appl Biochem Biotechnol 160:40-49.

Kunduhoglu B, Elcioglu O, Gezginc Y, Akyol I, Pilatin S, Cetinkaya A. 2012. Genotypic identification and technological characterization of lactic acid bacteria isolated from traditional Turkish Kargi tulum cheese. Afr J Biotechnol 11:72187226.

Lahtinen S, Ouwehand AC, Salminen S, von Wright A. 2011. Lactic acid bacteria: Microbiological and functional aspects. $4^{\text {th }}$ ed. CRS Press, New York, USA. p 286.

Macaluso G, Fiorenza G, Gaglio R, Mancuso I, Scatassa ML. 2016. In vitro evaluation of bacteriocin-like inhibitory substances produced by lactic acid bacteria isolated during traditional Sicilian cheese making. Ital J Food Saf 5:5503.

Perumal V, Venkatesan A. 2017. Antimicrobial, cytotoxic effect and purification of bacteriocin from vancomycin susceptible Enterococcus faecalis and its safety evaluation for probiotization. LWT- Food Sci Technol 78:303-310.

Pingitore EV, Salvucci E, Sesma F, Nader-Macias ME. 2007. Different strategies for purification of antimicrobial peptides from lactic acid bacteria (LAB). In Communicating current research and educational topics and trends in applied microbiology. Méndez-Vilas A (ed). Formatex, Badajoz, Spain. pp 557-568.

Phumisantiphong U, Siripanichgon K, Reamtong O, Diraphat P. 2017. A novel bacteriocin from Enterococcus faecalis 478 exhibits a potent activity against vancomycin-resistant enterococci. PLoS One 12:e0186415.

Rea MC, Dobson A, O’Sullivan O, Crispie F, Fouhy F, Cotter PD, Shanahan F, Kiely B, Hill C, Ross RP. 2010. Effect of broad- and narrow-spectrum antimicrobials on Clostridium difficile and microbial diversity in a model of the distal colon. Proc Natl Acad Sci USA 108:4639-4644.

Saelim K, Kaewsuwan S, Tani A, Maneerat S. 2015. Physical, biochemical and genetic characterization of enterocin CE5-1 produced by Enterococcus faecium CE5-1 isolated from Thai indigenous chicken intestinal tract. Songklanakarin J Sci Technol 37:299-307. 
Schägger H, Von Jagow G. 1987. Tricine-sodium dodecyl sulfatepolyacrylamide gel electrophoresis for the separation of proteins in the range from 1 to $100 \mathrm{kDa}$. Anal Biochem 166:368-379.

Sparo MD, Castro MS, Andino PJ, Lavigne MV, Ceriani C, Gutiérrez GL, Fernández MM, De Marzi MC, Malchiodi EL, Manghi MA. 2006. Partial characterization of enterocin MR99 from a corn silage isolate of Enterococcus faecalis. J Appl Microbiol 100:123-134.

Todorov SD, Dicks LMT. 2005. Lactobacillus plantarum isolated from molasses produces bacteriocins active against Gramnegative bacteria. Enzyme Microb Technol 36:318-326.

Todorov SD, Dicks LMT. 2006. Screening for bacteriocin-producing lactic acid bacteria from boza, a traditional cereal beverage from Bulgaria: Comparison of the bacteriocins. Process Biochem 41:11-19.

Vimont A, Fernandez B, Hammami R, Ababsa A, Daba H, Fliss I. 2017. Bacteriocin-producing Enterococcus faecium LCW 44: A high potential probiotic candidate from raw camel milk. Front Microbiol 8:865.

Xi Q, Wang J, Du R, Zhao F, Han Y, Zhou Z. 2017. Purification and characterization of bacteriocin produced by a strain of Enterococcus faecalis TG2. Appl Biochem Biotechnol 184:1106-1119.

von Right A, Axelson L. 2011. Lactic acid bacteria: An introduction. In Lactic acid bacteria: Microbiological and functional aspects. $4^{\text {th }}$ ed. Lahtinen S, Ouwehand AC, Salminen S, Von Wright A (ed). CRS Press, New York. USAs. pp 1-16.

Yamamoto Y, Togawa Y, Shimosaka M, Okazaki M. 2003. Purification and characterization of a novel bacteriocin produced by Enterococcus faecalis strain RJ-11. Appl Environ Microbiol 69:5746-5753.

Yanagida F, Chen Y, Onda T, Shinohara T. 2005. Durancin L28-1A, a new bacteriocin from Enterococcus durans L28-1, isolated from soil. Lett Appl Microbiol 40:430-435.

Yang SC, Lin CH, Sung CT, Fang JY. 2014. Antibacterial activities of bacteriocins: Application in foods and pharmaceuticals. Front Microbiol 5:1-10.

Yildirim Z, İlk Y, Yildirim M, Tokatli K, Öncül N. 2014. Inhibitory effect of enterocin KP in combination with sublethal factors on Escherichia coli O157:H7 or Salmonella Typhimurium in BHI broth and UHT milk. Turk J Biol 38:412-419. 